\title{
Review
}

\section{Citizenship and the pursuit of the worthy life}

\author{
David Thunder \\ Cambridge University Press, Cambridge, 2014, xv+210pp., ISBN: 978-1107068933
}

Contemporary Political Theory (2016) 15, e4-e6. doi:10.1057/cpt.2016.18; published online 28 June 2016

David Thunder's book is a fascinating analysis of the ethics of citizenship under conditions of contemporary constitutional democracy. The essay can be easily read as a classical treatise on ethics and virtue in the polis, and that is probably the reason for the specific style that characterizes it, so different from the usual tone of most contemporary social science and political theory books: there is no jargon, no unnecessary difficult passages, but flawless and always clear writing. Indeed Thunder's book has the great merit of proposing an ethical inquiry of civic engagement as a path toward human excellence. The main theme of Thunder's inquiry is integrity, more than citizenship itself: a human life can be fully lived only through an exigent and relentless quest of a person's main call, or, as the author writes, 'we might say that for the purposes of assessing the overall worth of a human life, what counts more than anything else is what a person is for' (p. 25). This requires ethical integrity, defined as 'a robust, enduring, and wholehearted commitment to integrate his desires, dispositions, actions, relationships and projects into what he responsibly and reflectively takes to be a worthy life' (pp. 27-28).

The institutions and the practices of citizenship are the framework through which ethical integrity can be expressed and learned. In the world of contemporary political reflection, the feeling of transcendence that is expressed by this definition of a worthy life is at the same time disconcerting, used as we are to judge political actions either by immanent rationality or by the structures of society itself, and refreshing. It may appear disconcerting for the reasons that Thunder himself acknowledges in the book: since the time of modern political thought, we are used to separate ethical and political reflections. Indeed questions that were asked by classical and medieval philosophers, such as Aristotle or St Augustine, have been expelled by the reflection of modern thinkers, like Machiavelli, Hobbes, Locke or Kant, given their belief that politics consists in guaranteeing the conditions of public order and justice, and that for this purpose exigencies of morality were useless.

Nevertheless, this theoretical heritage, together with the need, felt during the time of the European wars of religion, for separating private beliefs and the rules of public life, 
have produced a situation of apathy and disaffection in our constitutional democracies. The large part of the academic literature on citizenship deals with it as a set of laws, as a formal institution or as a set of social practices, insulating it from ethical concerns. For Thunder, this is deeply problematic, as it makes present democracy more vulnerable to those demagogues who understand that citizens need a sense of meaning and purpose in life, absent from an ethically emptied political scene. This situation contributes to the disaffection of citizens from political life, 'insofar as it fails to anchor civic life and its demands in values that people care about and strive to honor on a day-to-day basis' (p. 191).

Thunder is aware of the fact that what we may call 'active citizenship' is the privilege of a small part of the actual citizens of today's democratic countries, as in post-industrialised societies, civic engagement plays a peripheral role, given the actual division of labor. There is no need for the masses to be engaged in the public sphere; they can attend to their everyday life, often made of private interests, while a small part of the citizenry takes care of the public good. The author is not naïve when it comes to depicting the concrete situation of political commitment under conditions of contemporary democracy. On the contrary, he is aware of the danger that confronts a democratic regime that has no effective citizens, but only formal procedures to sustain it. His thesis is founded upon the notion of citizenship as an interdependent and inter-relational category; it provides a basis for perceiving and exercising the responsibilities that we have toward those who share our social space. Respecting the rule of law, and being committed to constitutionalism, are not enough as formal principles, as democracy requires self-integration, as a regulative ideal of inner harmony, to be nourished.

Thunder's thesis that there is a continuity between the ethical dimension of a worthy life and the political practice of citizenship rests upon two main hypotheses: the distinction between the ethical and the moral perspective, and the critique of the separation between individual autonomy and the social context. Let's take into account the first one: the ethical standpoint is always connected to the quest for human excellence, although not in an atomistic way, but taking into account the social context. The connection between the inner values and the social context is precisely what distinguishes it from the 'moral' point of view, which is instead constituted by obligations toward others and only marginally by the agent's character. This first distinction leads Thunder to a critique of the dominant approaches in political theory, namely John Rawls's political liberalism, according to which citizenship is interpreted as 'a role that enables us to achieve certain instrumental goods (wealth, personal security) or to honor our obligations toward others or to secure the exigencies of a just and stable social and political order' (p. 10).

Thunder's critique of Rawls and of general approaches that separate the ethical point of view from the moral and political ones is the object of the book's fourth chapter. It is indeed a merit of the book that it does not take for granted mainstream approaches in political theory, in particular political liberalism, but it opens 
up a more substantial ethical and political account of contemporary citizenship. Separatist approaches, such as the ones exemplified by Rawls and Reinhold Niebuhr, argue that political action is governed by distinctive purposes and principles that must be partially insulated, for practical purposes, from conceptions of a well lived human life. Thunder criticizes Rawls's separation between theories of the good (which should be influenced by contingencies) and theories of justice (which should not be). He also discusses Niebuhr's thesis concerning the necessity of departing, in the tasks of a citizen or statesmen, from the structures of 'a sensitive conscience' devoted to unselfishness and love (p. 109).

Thunder's approach is much more contextual and attentive to the social dimension of political theory than classical political liberalism. This is what he calls a 'situated approach', which is 'firmly grounded in the actual and contingent situation of persons'. According to this approach, the appropriate starting point for evaluating citizenship is not its ethical appeal in some carefully restricted choice situation, such as Locke's 'state of nature' or Rawls's 'original position', but the 'actual situation we find ourselves in, including our existing history, institutions, relationships and realistic opportunities for action' (p. 140).

The international and situated character of Thunder's approach is his main advantage over classical political liberalism when it comes to discussing contemporary citizenship. The main limits of Thunder's book, in my view, are the scant attention he pays to the other part of the continuum between ethics and politics, which is politics. Indeed, citizenship is very well investigated in its ethical dimension, and this is the original and refreshing contribution of his book, but very little is said on the political dimension of this practice. The argument of the book would have been enriched by a bold step into the realm of the effective conditions of civic engagement under contemporary democracies, in order then to come back to its ethical counterpart.

Teresa Pullano

University of Basel, Basel, Switzerland teresa.pullano@unibas.ch 